\title{
Life Story of Persons With Paraplegia in Achieving Post-Earthquake Resilience in the Bantul District
}

\author{
$1^{\text {st }}$ Astri Hanjarwati* \\ Departement of Sociology \\ UIN Sunan Kalijaga \\ Yogyakarta, Indonesia \\ astri020585@gmail.com
}

\author{
$2^{\text {nd }}$ Muh Aris Marfai \\ Departement of Enviroment \\ Gadjah Mada University \\ Yogyakarta, Indonesia \\ arismarfai@yahoo.com \\ $4^{\text {th }}$ R Rijanta \\ Departement of Regional Development \\ Gadjah Mada University \\ Yogyakarta, Indonesia \\ Rijanta@ugm.ac.id
}

\author{
$3^{\text {rd }}$ M Pramono Hadi \\ Departement of Enviroment \\ Gadjah Mada University \\ Yogyakarta, Indonesia \\ mphadi@geo.ugm.ac.id
}

\begin{abstract}
The purpose of this study is to reveal the life journey of people with parapelgia in achieving resilience as a new diffable due to the earthquake disaster. This research is a narrative qualitative study by conducting in-depth interviews with 10 people with paraplegia victims of the Bantul earthquake. The analysis process carried out is to make generalizations and interpret the journey's story from the informants and make conclusions on the life's journey story that is told in detail. The results of research Resilience of people with paraplegia can be achieved in four phases namely the stress / depression phase, the phase of self-acceptance and adaptation, the phase of self-development and capacity building, and the phase of resilience where people with paraplegia are said to be resilient if they are able to be independent in mobility, productive and socializing. The determinants of resilience are self, family, government, friends and accompanying NGOs.
\end{abstract}

Keywords-life story, people with paraplegia, resilience, postearthquake

\section{INTRODUCTION}

The earthquake victims who are disabled are those who have suffered a spinal cord injury (Spinal Cord Injury /SCI /paraplegia), amputated both feet and hands, fracture femur and vertebral fractures. Based on WHO data in 2007, the districts with the highest number of paraplegia sufferers were Jetis District (92 inhabitants), Pundong District (55 inhabitants), Bambanglipuro District (44 inhabitants), Piyungan District (9 inhabitants), Pleret District (48 inhabitants), and Sewon District (67 people). Disasters are always related to the level of vulnerability of a person or the environment. Natural events (hazards) such as earthquakes are not necessarily called disasters if they do not claim fatalities or material damage [1]. This means that vulnerability causes a hazard to become a disaster [2]. However, the vulnerability of each person and society is different so that despite experiencing the same natural disaster can give different impacts for each person/group [3]. Likewise, people with paraplegia who become disabled due to earthquakes, It is not easy for them to adapt to life with several limited conditions.

Data from the DIY Social Service (2011) shows the fact that disabled persons after the earthquake in DIY only $49 \%$ were able to recover again to become independent individuals. They continue their education, work and can access public services as before. While the rest who have not been able to handle and are still dependent on families classified as having limited access to public services. In the current period when the disaster happened, the government and the community only focused on the process of evacuation, recovery, and rehabilitation. Meanwhile, how to increase resilience when a disaster recurs or after a disaster is not becomes a focus, hence disaster victims tend to continue to increase. Research on resilience has been carried out since there have been studies of disasters. Research topics on resilience are very diverse ranging from the preparation of resilience indexes, methods used in researching resilience, factors that affect community resilience in the aftermath of a disaster, strategies in increasing community resilience to face disasters and how to build resilience.

The lives of people with paraplegia before the earthquake and after the earthquake experienced significant changes, from normal life as non-disabled and post-disaster to disabled, namely people with paraplegia. This condition is certainly not easy to live and the results of this study will enrich knowledge about resilience studies. Discussion and grouping of previous studies on resilience are as follows. Hizbaron (2011) examined the integration of Disaster Risk Reduction (DRR) into disaster risk-based spatial planning in Indonesia, building a conceptual framework that led to a comprehensive integration of vulnerability assessments and analyzing vulnerabilities at the micro level [4]. This research indicated that to understand the importance of spatial planning with vulnerability information is insufficient. It showed that there is a difference between theory and practice, namely the use of spatial plans to reduce the level of vulnerability has not been implemented, thus leaving further development to achieve a safer environment.

Zhang (2011) examined the resilience of urban disasters conducive for better understanding of disaster prevention and mitigation capacity and provided valuable references for resilient city development. The results showed that the physical and social endurance of the City of Shenzhen showed a clear trend of spatial concentration [5]. Damayanti \& Marfai examined the resilience of post-disaster 
communities [6]. How they created resistance after being hit by a disaster [7]. The aspect distinguished those four studies is the location of the study and the method used in each study. The results of this study are the strategies used by the community in living post-disaster life [8].

Irshad conducted the same research subject with what previous researchers have done about people with paraplegia who were victims of the earthquake disaster in Nepal. But the research topic is different, namely about the different treatments received by men and women paraplegia after they become people with paraplegia. This study used a gender perspective with ethnographic methods. The results of the study were that male paraplegia received more honor or priority than women. Women experienced discrimination at various levels of life in society[9]. Kusumastuti conducted research that produced a resilience index, a resilience framework and a theoretical resilience framework [10]. These studies contributed to the theoretical development of the theory of resilience so it can be used by researchers who will examine resilience.

Witt and Lill tried to provide the latest information on research methodologies currently used to inform researchers about contemporary research practices and to identify trends and possible gaps to offer opportunities for innovation / novelty and knowledge enhancement about research methodology on the topic of resilience [11]. Based on the 156 articles analyzed, it was found that the qualitative approach dominated in resilience research. Collected data in the study was mainly from literature and interviews. Previous studies were type of case study research which develop theoretical and conceptual frameworks and carried out by researchers and it concluded as sample study rather than studies that develop toolkits and practical guidelines.

Mc Entire et al., (2002) explained that natural disaster analysis has traditionally focused on the concepts of vulnerability, risk, and emergency management [12]. Gunerson, (2010) stated that resilience theory views natural disasters as disruptions in the socio-ecological system [12]. Resilience theory can add value to disaster management through its emphasis on complex system dynamics (ie uncertainty, non-linearity); ideas of flexibility, novelty and innovation; and multi-scale perspectives (spatial and temporal). Thus, the resilience approach can support more proactive involvement in managing change such as human responses to, and recovery from, natural disasters.

Personal resilience is described as one's capacity to adapt psychologically, emotionally and physically quite well and without harming oneself, relationships or personal development in the face of difficulties, threats or challenges[13]. In the literature on political ecology and changes in the global environment it is explained that the concept of adaptive capacity, namely the ability of a system to adapt to change, moderate effects and overcome disruption[14]. The Department of International Development-DFID defined disaster resilience as the ability of communities and households to manage change, through maintaining or changing living standards in the face of shocks or pressures [15].

This study aims to reveal the life journey of people with paraplegia in achieving resilience as a new diffable due to the earthquake disaster. This research is a qualitative narrative study by conducting in-depth interviews with 10 people with paraplegia victims of the Bantul earthquake. The analysis process carried out is to generalize and interpret the journey's story from the informants and make conclusions on the life's journey story that is told in detail.

\section{LIFE STORY OF PERSONS WITH PARAPLEGIA IN ACHIEVING RESILIENCE}

\section{a. NP (Female, District of Sewon)}

At the time of the 2006 earthquake, NP was 14 years old (2nd grade/class at junior high school). NP suffered a broken back due to due to the even there was falling wood on her roof and made her injured. After receiving treatment at Sarjito Hospital, NP attended rehabilitation at YAKKUM. When attending NP rehabilitation, she also attended the Hamongputera Junior High School in Sleman and left her old school MTs N Gondowulung Sewon. After graduating from junior high school, NP continued to study at SMK Muhamadiyah 1 Yogyakarta. In her daily activity, NP used motor modifications, so it is quite independent. NP is actively engaging in in disabled organizations. And she is the youngest member of the Yogyakarta paraplegia organization.

Her life began to change, and she found her passion in 2009 after learning tennis for the disabled. In 2012, NP participated in the first competition at the 2012 Peparnas (National Paralympics Week) in Riau. At that time NP and Bantap Regency paraplegia organizations could only practice at least once a week. In 2018 the NP was chosen to be Indonesia's representative for the 2018 Asian Paragames multi-level event in which Indonesia is the host. NP is registered in the International Tennis Federation (ITF) ranked 85th in the world.

NP has participated in many tennis competitions for the disabled both at the national and international levels. In national level, NP was participated in 11 tennis competitions from 2012-2019 by getting 8 gold, 4 silver and 5 bronze. While in the international competition, NP followed 7 races since 2018-2019 by obtaining 1 gold, 3 silver and 2 bronze.

The story of NP's journey becoming, without to tennis athlete is inseparable from the support of both parents, friends of the organization, accompanying NGOs namely YAKKUM and the government which has provided facilities for NP to be able to achieve its goals as a tennis athlete. In the past NP felt devastated because he was still a teenager convicted of being disabled, but now that feeling turned into gratitude because if he did not become disabled, NP would not necessarily be an athlete like now.

\section{b. EN (Female, Jetis District)}

EN at the time of the 2006 earthquake was 19 years old and enrolled in the mathematics department of UNY in the fourth semester. At the time of the EN earthquake the spinal cord was crushed due to a fall on the wall of her collapsed house. At that time EN was hospitalized at Sarjito Hospital and felt shocked when she learned that she was disabled for life and became a person with paraplegia. The family, especially the mother and her younger sibling, have a role in motivating EN to accept destiny gracefully and begin with a new life as a person with paraplegia. Approximately 7 months, EN is able to accept her condition as a person with 
paraplegia when she has gathered with friends who are in the same boat at YAKKUM to participate in rehabilitation.

EN attended rehabilitation at YAKKUM around 6 months to be able to adjust using a wheelchair in daily activities. Unfortunately, because she did not feel confident, EN did not continue her study at UNY. After YAKKUM, EN participated in many trainings to increase her capacity to be able to live independently. Aside from participating in training, she is also active in the Bantul disability organization. In daily activities EN uses motor modifications and wheelchairs so that she can go anywhere and does not need to be delivered because able to do it by herself.

At present EN is the secretary of the P3Y Organization, a disabled organization formed after the earthquake. The occupational profession undertaken by EN is trading online and also sewing clothes. With these two professions, EN is able to live independently to support her daily life. EN lives with her parents who are elderly. EN's house is very accessible for wheelchair users and there are no obstacles for EN to do all its own activities.

\section{c. LS (Male, District of Pleret)}

At the time of the earthquake LS was 28 years old and his wife was pregnant ( 2 months). The earthquake disaster drastically changed the happiness of his little family. He experienced depression for 1 year because he could not accept his condition as a person with paraplegia. His wife was the one who became a motivator for LS until he was able to survive until now. In fact both LS parents are people who make LS more depressed because LS parents cannot accept LS conditions. LS parents force LS to continue learning to walk and say that LS cannot walk because LS is lazy to learn. Even though the doctor had told the LS and his family that $\mathrm{t}$ LS had experienced total paralysis and became a person with paraplegia.

After returning from Sarjito Hospital, LS attended rehabilitation at YAKKUM to be able to make new adjustments to the wheelchair. LS spend the rehabilitation approximately for about 4 months in YAKKUM. After YAKKUM, LS returned home and got a lot of pressure from his parents. the most interesting training for EV after a year running and the birth of his first child makes LS become enthusiastic and try to be independent and able to support his family.

LS attended many capacities building training and the most interesting thing was sewing training. LS until now works as a tailor and his wife works as a caregiver for neighboring children to supplement family income. In domestic life LS feels grateful to have a wife who is able to motivate, help, and assist LS in going through all these difficult processes. LS child is now ready going to school to school and become healthy and smart child, both of which make LS keep the spirit in living a difficult life as a person with paraplegia.

\section{d. NR (Female, Jetis District)}

The 2006 earthquake was the hardest test for NR and her husband. During the earthquake NR was badly injured in the back due to a building being hit while NR was cooking. Her only child, who at that time was 3 years old, fell on two sides of her wall while running away wanting to save herself from an earthquake. This incident made the husband and NR very devastated especially after learning that NR could not recover and become a person with paraplegia.

NR and her husband need a long time to be able to recover about 2 years from the earthquake disaster has occured. NR almost committed suicide because of lamenting his fate of being a person with paraplegia and losing his only son. Gratefully, her husband saw the NR action and was able to her suicidal attempt. Then both of them often pondered, the story with the kyai and friends who experienced similar event hence their sense of disappointment and deep sadness disappeared. Then they surrender that all events and destiny come from God, God will not give a test if humans are not able to live it.

NR's husband always accompanies NR in doing all activities, taking NR wherever he goes. Gathering with fellow paraplegia is awaited by NR and her husband. NR and her husband diligently participated in the organization's activities starting from recitation, social gathering, training and picnics to be able to relieve stress and depression from gathering with people in the same boat. NR is now knitting bags to help her husband make a living. Until now NR and her husband were not blessed with offspring and lived alone.

\section{e. EV (Female, Bambanglipuro District)}

EV was 17 years old, sitting on the 2nd grade of vocational high school when the 2006 earthquake struck. EV was injured in the spine due to the falling wall which hit her when she was going to save herself from the earthquake. EV was evacuated from the rubble in a long time about 3 hours because there was a tsunami issue that caused all the people to flee to the mountains. the evacuation process, EV was treated at Sarjito Hospital and until healed. When the doctor said that EV became a person with paraplegia, EV and her parent felt devastated because EV was still very young.

After leaving Sarjito Hospital, EV continued her rehabilitation at YAKKUM to adjust activities with a wheelchair. EV was in YAKKUM for 3 months and after that EV continued to attend vocational school until graduation. EV gets support from both parents to be active and continue to learn as a provision of life. EV actively participates in training at BRPTD, training from NGOs and also training from universities. the most interesting training for $\mathrm{EV}$ is office and computer administration. In addition. $\mathrm{EV}$ is also active in disabled organizations that have been formed after the earthquake disaster.

In his journey EV was married to a fellow AF paraplegia from Pundong District. They know each other in the P3Y organization (Paraplegia Persons Association of Yogyakarta). EV currently works in an NGO that focuses on empowering people with disabilities. While her husband has a self-employed workshop. At present EV is blessed with a daughter who is 2.5 years old. In the journey from postdisaster until now, the people who played the most significant role were EV parents who always motivated EV to keep her spirits up with all the conditions. In addition, facilities from the government and foundations for increasing EV capacity through training are also the biggest contribution to EV so that she can live independently. 
Organizations and friends with disabilities also play a role in the process of her achievement today.

\section{CONCLUSION}

Based on the results of research, the factors of resilience / resilience of people with paraplegia are divided into two main factors, namely resilience / resilience individually and community resilience / resilience. The community referred to in this study is a community with paraplegia.

The process of resilience / resilience of people with paraplegia consists of several stages (1) Phase stress and depression, (2) Phase of self-acceptance and adaptation, (3) Phase of self-development and capacity building and (4) Phase of Resilience. In reaching each phase, paraplegia is supported by internal and external factors [16]. Internal factors are factors originating from persons with paraplegia, while external factors are supporting factors that come from family, friends, government and NGOs.

The process from first phase to the second phase based on the results of the study took months to 2 years. It depends on the personal conditions of each person with paraplegia. Internal factors that support this achievement were the communication skills of people with paraplegia for example expressing their sadness, disappointment and problems to other people. Meanwhile for external factors were support from family, friends, Government and NGOs in the form of psychological assistance, mobility training as persons with paraplegia, and the establishment of disabled organizations to strengthen the disabled community.

The process from the second phase to the third phase took 1-2 years. The success of each individual is different, depending on the willingness to be independent from people with paraplegia and the optimistic attitude of people with paraplegia. External factors which gave influence were in the form of family support (freedom of activity), support from the Government (training to improve skills, providing capital in the form of money and work equipment) and from NGOs (training to improve skills).

The dominant factor influencing the resilience / resilience of paraplegia communities was economic development and social capital of paraplegia communities. Economic development is carried out in several stages, namely the provision of equitable home recovery assistance to all victims of the earthquake disaster, providing training in independence of mobility to people with paraplegia, providing training in increasing skills and providing capital assistance and equipment to people with paraplegia. The social capital of the paraplegia community consists of receiving social support, relationships and cooperation within the organization, leadership from the diffable and participation of the paraplegia person in the community.

The dominant factor affecting resilience / resilience of individuals with paraplegia was social support and communication skills. With social support from family, friends and the government and NGOs, people with paraplegia are able to stand up from adversity (stress, depression due to being disabled), have an optimistic attitude, are able to solve problems and are able to adapt to the new environment and conditions.
Suggestions for future research with the theme of resilience can then be focused on subjects with other types of disabilities, such as the blind, deaf and mentally disabled.

\section{ACKNOWLEDGMENT}

This paper is part of the results of dissertation research in the doctoral program in Geography, Faculty of Geography, UGM. Research funding is supported by the Ministry of Research and Technology, through a 2013 Postgraduate Domestic Education scholarship.

\section{REFERENCES}

[1] Person C and Fuller E J 2007 Disaster Care for Persons With Psychiatric Disabilities Recommendations for Policy Change 23849

[2] Sanderson D 2013 Disasters and Livelihoods Cities , 2 49-58

[3] Iwata K, Ito Y and Managi S 2014 Public and private mitigation for natural disasters in Japan Int. J. Disaster Risk Reduct. 7 39-50

[4] Dyah Rahmawati Hizbaron 2011 integration of vulnerability assessment into seismic based spatial plan in bantul, yogyakarta, indonesia. (Gadjah Mada University)

[5] Wu L, Zhou H, Zhang S, Li L, Zhang M and Ji C 2018 Spatialtemporal variations of natural disasters during the Ming \& Qing Dynasties (1368-1912AD) in Chaohu Lake Basin, East China Quat. Int. $467242-50$

[6] Damayanti S 2011 Disaster and Resilience for the 2007 Flood Event in Part of Sukoharjo Regency 43 111-22

[7] Wright K 2016 Resilient communities? Experiences of risk and resilience in a time of austerity Int. J. Disaster Risk Reduct. 18154 61

[8] Lam L M and Kuipers R 2019 Resilience and disaster governance: Some insights from the $2015 \mathrm{Nepal}$ earthquake Int. J. Disaster Risk Reduct. 33 321-31

[9] Irshad H, Officer H and Health C 2012 Long-term gendered consequences of permanent disabilities caused by the 2005 Pakistan earthquake 36 65-74

[10] Kusumastuti R D, Viverita V, Suardi L and Nastiti D 2014 Author s Accepted Manuscript disasters in Indonesia Int. J. Disaster Risk Reduct.

[11] Witt E and Lill I 2018 Methodologies of contemporary disaster resilience research Procedia Eng. 212 970-7

[12] Leitch A M and Bohensky E L 2014 Return to 'a new normal': Discourses of resilience to natural disasters in Australian newspapers 2006-2010 Glob. Environ. Chang. 26 14-26

[13] Williams R 2009 Psychosocial resilience and its influence on managing mass emergencies and disasters Psychiatry 8 293-6

[14] Manyena S B 2014 Disaster resilience: A question of 'multiple faces' and 'multiple spaces'? Int. J. Disaster Risk Reduct. 8 1-9

[15] Islam R and Walkerden G 2014 International Journal of Disaster Risk Reduction How bonding and bridging networks contribute to disaster resilience and recovery on the Bangladeshi coast Int. J. Disaster Risk Reduct. 10 281-91

[16] Hanjarwati A, Marfai M A, Pramono M and Rijanta R 2020 Resilience of persons with paraplegia for earthquake disaster victims in Bantul Regency IOP Conf. Ser. Earth Environ. Sci. 451 